\title{
PROFESSIONAL STRESS MANAGEMENT IN THE WORK OF A SELECTED GROUP OF UNIFORM SERVICES - CASE STUDY
}

doi: $\quad 10.2478 /$ czoto-2019-0025

Date of submission of the article to the Editor: 12/12/2018

Date of acceptance of the article by the Editor: 15/02/2019

Piotr Placek ${ }^{\mathbf{1}}$ - orcid id: 0000-0002-9086-2960

${ }^{1}$ Central School of the State Fire Service in Częstochowa, Poland, placekp@wp.pl

Abstract: Work in uniformed services carries a high risk of losing health and even life. The occupational activities undertaken are related to exposure to factors belonging to the group of dangerous (accident) hazards. The work of uniformed services is also a work of high psychosocial risk. It can be said that the stress at work of firefighters or policemen is an everyday reality, which they deal with in different ways. This paper deals with the analysis of occupational stress at work of uniformed services on the example of employees of the State Fire Service. To analyze and assess occupational stress the European Foundation checklist for the Improvement of Working and Living Conditions has been used.

Keywords:occupational health and safety, uniformed services, occupational stress, psychosocial risks

\section{INTRODUCTION}

Psychosocial hazards are increasingly present in the professional life of people. The literature of the subject defines this type of threat as a condition caused by the employee's perception of phenomena in the work environment, which are assessed as unfavorable or dangerous. Psychosocial hazards concern those aspects that are inseparably connected with the way of planning and organizing work, as well as environmentally and individually felt effects, that is the increasing level of stress causing deterioration of the psychophysical health of employees (Hajdas and Niciejewska, 2017; Warchol, 2010).

There are many definitions of psychosocial risks. However, all of them relate to the relationship between the content of work, organization of work, as well as management systems, working environment conditions, and competencies, needs and individual limitations and capabilities of the employee. The World Health Organization as well as the European Agency for Safety and Health at Work treat the concept of psychosocial risks very broadly. The group of psychosocial risks includes, among others globalization, new forms of employment contracts, lack of permanent employment contracts, aging of the workforce, etc. Treatment of psychosocial factors 
in the hazard category also extends the definition of the work environment, which consists of all the conditions of both the physical environment (physical, chemical, biological) and non-material factors (psychosocial factors). The group of psychosocial factors includes conflicts, haste in performing tasks, unadjusted effort, both material and personal responsibility. All these factors can be stressful. Thus, psychosocial risks are associated with the risk of stress at work (Gólcz, 2015; Hajdas and Niciejewska, 2017; Niciejewska and Klimecka-Tatar, 2018)

So what is stress? The stress is the state of organismstimulation, which is the result of the factorseffect in the material or social environment, assessed as exposing the wellbeing. Stressthreats the physical or mental balance of the organism beyond the ability to deal with the problem (Ellis, 1996).

Hans Salye (1956) hypothesized that the source of a number of somatic diseases is stress. According to this assumption, the disease may be the result of the inability of a person to deal with stress. This phenomenon has been described as the failure of the so-called general adaptation syndrome (GAS). Since then, on the subject of stress, over 1,400 academic papers and 30 books with Salye co-authorship have appeared. That is why Salye is considered as the precursor of this phenomenon. Since Salye's time, many publications and scientific studies have been described about stress, especially stress related to professional work. Cox, in turn, presented the definition of stress as a condition characterized by strong negative emotions, such as fear, hostility, as well as other emotional states, causing stress and related physiological and biochemical changes, clearly exceeding the normal state. The factor causing stress is the occurrence of discrepancies between the requirements and the individual's ability to deal with them. Thus stress can be understood as physiological and psychological reactions to unusual and usually unpleasant situations or threatening events in the environment (Cox et al., 2006).

The output of scientists, theoreticians and practitioners, today points to three existing approaches to defining and testing stress. The first one, engineering, describes stress as an aversive or harmful property of the environment (in research it treats as an independent variable), the environmental cause of bad health condition. The physiological approach defines stress as the combined physiological effects of a wide range of aversive and harmful stimuli. Thus, stress is treated as a special physiological reaction to a threatening or harmful environment. According to the third psychological approach, stress is defined as the dynamic interaction between man and the work environment (Cox et al., 2006).

The above-mentioned approaches to stress have, of course, received many critical remarks. The first two approaches, engineering and physiological, treat man as a passive entity transporting stimuli coming from the environment to psychological and physiological parameters of reaction. Thus, in this approach, the interactions between humans and diverse environments are ignored, which is in turn the main part of the system approach to biology, behavioral description and psychology. The third approach, psychological, considers the environmental, psychosocial and organizational context of stress that is related to work to be important. In this approach to the presence of stress, it proves based on the existence of complicated interactions of man with the environment. The psychological approach prevails in contemporary stress theories. For reasons of occupational stress, the literature on the subject is considered by both psychosocial and physical factors. The most common is the division into such types (sources) of the causes of stress presented in Figure 1. 


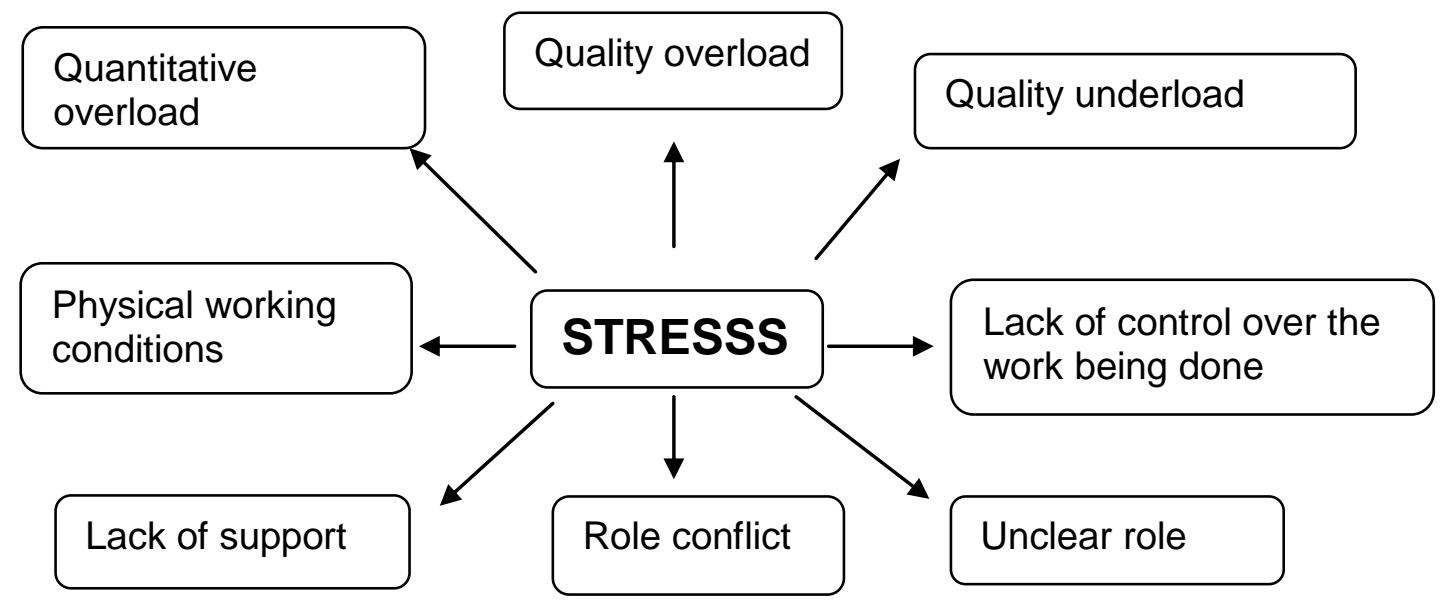

Fig. 1. Causes of professional stress

Source: own study based on Gólcz, 2015

Psychosocial risks, including stress, can be caused by (Ulewicz and Niciejewska, 2016):

- working conditions - working hours, shift, lack of availability to breaks and days off, nature of work, wages, contract type;

- $\quad$ physical factors - noise, temperature, dirt, work in harmful working conditions;

- tasks - too much, too little, too difficult, too easy, no control, monotony, time pressure, work pace, nature of work, type of work;

- tools and technology - workplace equipment, ergonomics, etc.

There are many stressful situations in the work environment. The reasons for stress can be seen, among others in (Mazur and Niciejewska, 2016; Ulewicz and Niciejewska, 2016):

- tasks requiring constant concentration,

- monotonous tasks - requiring precision,

- tasks requiring high physical effort,

- hurried tasks - high work speed, rigid time frame and unstructured system,

- tasks in which there is competition and conflicts,

- tasks with low prestige, responsibility, risk awareness, lack of control, moral dilemmas,

- tasks in which availability is important, work occurs in shifts and is often "taken" home, etc.

The effects of occupational stress can be different and have different effects on human health. The literature on the subject examines the effects of stress in three aspects that contribute to well-being: physiological, mental and social. Work in uniformed services carries a high risk of losing health and even life. Occupational activities are determined by factors belonging to the group of dangerous (accident) hazards (Lusa et al., 2002). The work of uniformed services is also a work of high psychosocial risk. It can be said that the stress at work of firefighters or policemen is an everyday reality, which they deal with in different ways (Strahler and Ziegert, 2015). Less stress means satisfied and motivated employees (Dziuba, Ingaldi, 2016). 


\section{METHODOLOGY OF RESEARCH}

The survey is a cognitive tool that has been used in research. Analyzes and assessments of occupational stress at a selected position have been made on the basis of a checklist developed by the European Foundation for the Improvement of Working and Living Conditions. The checklist consists of 20 assumptions for which the respondent must answer "yes" or "no". Table 1 presents the issues of the said checklist.

Table 1.

Issues related to occupational stress according to the European Foundation for the Improvement of Working and Living Conditions

\begin{tabular}{|l|l|}
\hline No. & Issues related to work stress \\
\hline 1. & Short cycle work (less than 90 seconds) \\
\hline 2. & Monotonous and difficult tasks \\
\hline 3. & Require high concentration \\
\hline 4. & Work divided into small parts \\
\hline 5. & Work that places high emotional demands \\
\hline 6. & Work under pressure of and deadlines \\
\hline 7. & There are individual positions in the department \\
\hline 8. & Often, the departments are not properly prepared \\
\hline 9. & Often, the organization of work is not properly \\
\hline 10. & Insufficient support from other departments \\
\hline 11. & Frequent problems with equipment, machines, devices, etc. \\
\hline 12. & Lack of regular consultations at work \\
\hline 13. & Adjustment of the pace of work is impossible or difficult \\
\hline 14. & Difficult possibility of defining work methods \\
\hline 15. & Difficulties in the mutual assistance of employees \\
\hline 16. & Insufficient information on the results of work \\
\hline 17. & No time for short chats with colleagues \\
\hline 18. & Difficult contact with the supervisor in case of problems \\
\hline 19. & No contacts available to discuss issues \\
\hline 20. & A lot of conflicts at work \\
\hline
\end{tabular}

Source: own study checklist developed by the European Foundation for the Improvement of Working and Living Conditions

36 respondents took part in the anonymous study. All respondents were active firemen in the service of the State Fire Service of the Silesian Province. Respondents had to indicate which of the above issues appear in their professional work. Next, all answers to "yes" (points) should be summed up and determined according to the three-degree scale (Table 2), what is the level of occupational stress: "small", "medium" or "large".

Table 2.

The level of psychological load (stress) according to the three-level scale

\begin{tabular}{|l|l|l|}
\hline small & medium & large \\
\hline $0-3$ points & $4-11$ points & $12-20$ points \\
\hline
\end{tabular}

Source: own study checklist developed by the European Foundation for the Improvement of Working and Living Conditions 


\section{RESULTS AND DUSCUSSION}

In general, the results of the study has shown that occupational stress in firefighter's work is at the level of medium stress (about 9 points) in the minds of employees. In Figure 2, the collective results of the survey among firefighters have been summarized.

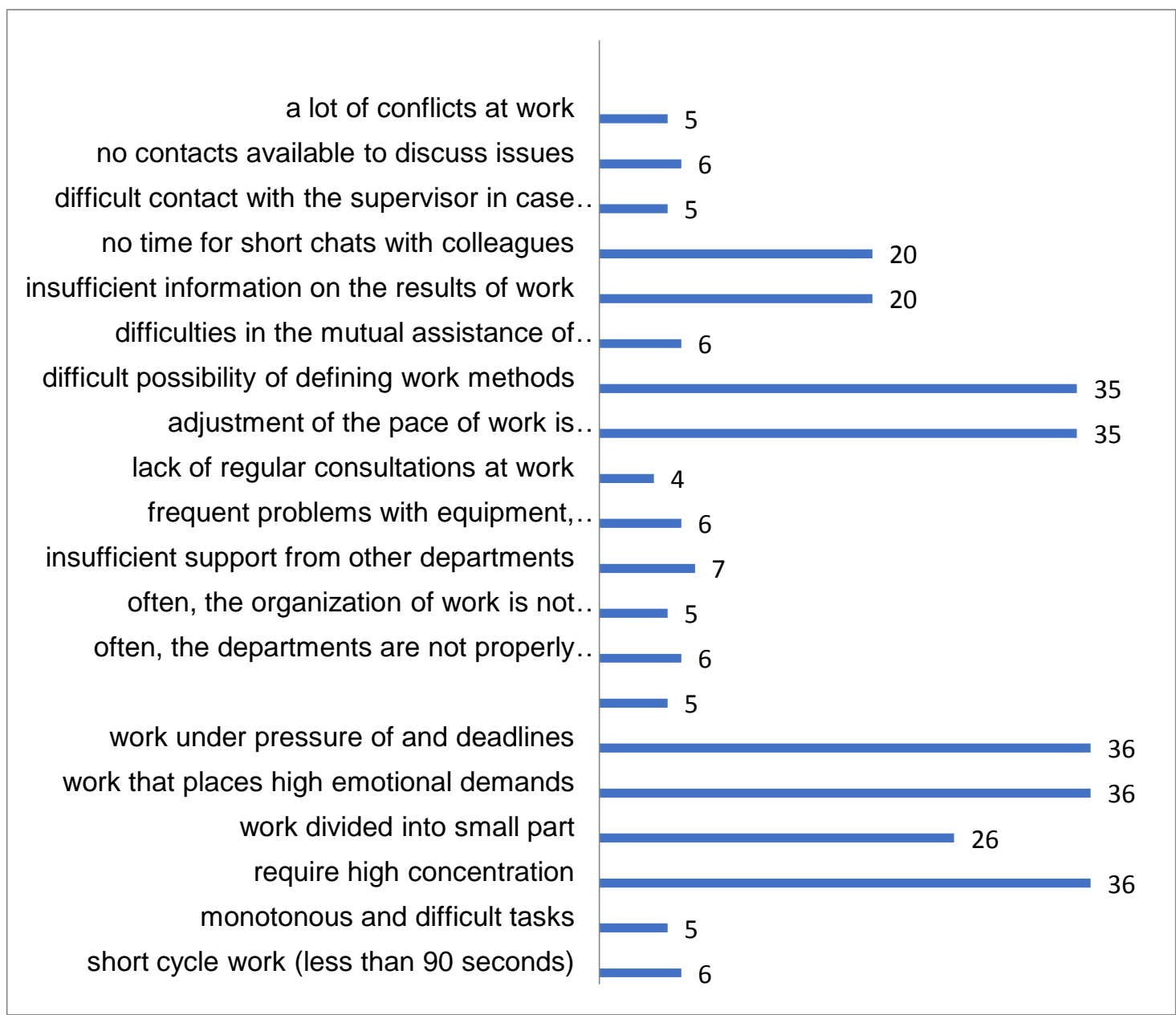

Fig. 2. Test results regarding the level of psychological load (stress) in fireman's work ( $n=36)$

For the main cause of stress, all respondents indicated "work that places high emotional demands". Fireman work requires a lot of physical fitness, concentration and self-control. Their tasks carry many threats to health and even life. Even one mistake they make during a rescue operation can pay for their lives, including coworkers. Fireman's work also means strict operating procedures that must be meticulously followed. Therefore, respondents indicated "work under pressure of time and deadlines" for another reason of high professional stress. It refers primarily to the time that firefighters have during a firefighting operation combined with a rescue operation. Their tasks are not only putting out fires, it is also bringing people out of burning rooms, stuck passengers in cars that have suffered an accident, etc. Saving human life often have a limited time of action, which intensifies the feeling of stress in them.

Next, all respondents have said that their psychological burden is also influenced by the fact that the tasks they perform "require high concentration". Then, their sense of stress is also affected by the fact that firefighters have "difficult possibility of defining 
work method". Uniformed services, including the State Fire Service, have very strictly hierarchical organizational structure and very strict procedures. This also includes methods and work tools imposed by predetermined operating procedures. In some situations, they can cause stress, especially in making decisions that are not specified procedural and occurred during work.

Generally, rigidly defined procedures in such a demanding profession as a firefighter's profession is a rather positive phenomenon. Another factor that causes State Fire Service employees to feel a strong psychological burden while working is "adjustment of the pace of work is impossible or difficult". In the firefighter's work there are situations when the safety conditions do not allow immediate action, or the employee has the opposite situation, he must intensify the pace of action to safe and effective execution of tasks. Undoubtedly, this is a big problem for firefighters. Another factor determining the sense of stress in the firefighter's work is "no time for short chats with colleagues" and "difficulties in the mutual assistance of employees". During the field visits, rescue operations and firefighting activities, there is no time for any chats. Under such conditions, employees often use abbreviations, commands, industry phrases that result from the nature of work and procedures. The lack of mutual assistance may result from the nature of the situation that may develop during firefighting or rescue work. In general, fire brigade staff should always be confident in helping each other during the action.

Studies have shown that the psychological load on the firefighter's work is on the medium level (with an indication of the upper limit of the score). The everyday work of a firefighter is connected with the necessity of observing drastic images of incinerations, destructions of various character and scale. Often these are images that people cannot get rid of from their memory after one day (Khan et al., 2018). Professional stress at work of a firefighter is a factor that often determines professional work but also functioning outside it. There is a need to properly manage this "hidden" threat which is stress. There are many methods and tools that allow to minimize occupational stress and its effects.

The psychological balance of an employee such as a firefighter is a priority that is difficult to achieve (Amstrong et al., 2009; Van Mol et al., 2019). Since stress is considered one of the main, hidden - occupational hazards, more and more specialists are trying to determine effective ways of dealing with it. Literature presents different methods of dealing with stress. Arranges them according to three levels: individual, organizational, systemic. On an individual level, stress can be dealt with by reducing the stressor, anti-stress exercises (various types of relaxation techniques) and removing distant effects (Niciejewska and Olejniczak, 2016). At the organizational level, can fight stress by changing the way of work, change management or motivation in work. On the other hand, at the systemic level, stress can be minimized by adapting work to the possibilities and limitations of the employee, through health care programs and with the help of appropriate health protection systems (Ulewicz and Niciejewska, 2016). In the State Fire Service, professional stress management is carried out at all three levels. The employee is treated in an individual way and vulnerability to stress is monitored and the tasks during the operation are examined. The organization of specialist training in dealing with a strong psychophysical burden, with particular emphasis on mental stress, is a priority in such an organization. The fire service staff also protects the systemic approach to stress management resulting from the nature and specificity of the firefighter profession. 


\section{CONCLUSION}

Effective management of professional stress in the work of uniformed services, especially employees of the State Fire Service must be based primarily on reliable identification of the psychophysical threats sources. Then, in cooperation with individual employees (individual approach) are developed methods and tools that support the understanding of the origin of stress and the methods of limitation. Of course, stress management at the individual level will be effective if it is based on a simultaneous organizational and systemic approach. Employee's confidence in the effectiveness of professional stress management resulting from high psychophysical load must be a priority. The work of a firefighter belongs to this type of work, in which a high level of psychological load is noted. There is a great need to manage it in an established triad - an individual, organizational and systemic approach, with particular emphasis on appropriate tools to minimize the negative effects of occupational stress.

\section{REFERENCES}

Amstrong, A., Alvero, R.J., Dunlow, S., Stewart, E. 2009. Balancing the Professional and Personal. Fertility and Sterility, 91,18-21.

Cox, T., Groffiths, A., Rial-Gonzales, E. 2006. Badania nad stresem związanym z pracą, Wyd. CIOP-PIB, Warszawa.

Ellis, J. R. 1996. Discovery of molecular chaperones, Cell Stress Chaperones. 1.

Gólcz, M. 2015. Stres w pracy. Poradnik dla pracownika. Wyd. PIP, Warszawa.

Hajdas, D., Niciejewska, M. 2017. Identyfikacja $i$ analiza zagrożeń powodujących wypadki w pracy strażaka ochotniczej straży pożarnej. In: Bylok, F., Zadros, K. (ed.). Bezpieczne środowisko pracy. OWSMJiP, Częstochowa.

Dziuba, S.T., Ingaldi, M. 2016. Employees Satisfaction in Chosen Metallurgical Company as an Element Influencing Quality of Finished Products. In: 25th Anniversary International Conference on Metallurgy and Materials, Ostrava, Tanger, 1769-1775.

Khan, K., Charters, J., Graham, T. L., Nasriani, H. R., Ndlovu, S., Mai, J. 2018. A Case Study of the Effects of Posttraumatic Stress Disorder on Operational Fire Service Personnel Within the Lancashire Fire and Rescue Service. Safety and Health at Work, 9, 277-289.

Lusa, S., Hakkanen, M., Luukonnen, R., Viikari-Juntura, E. 2002. Perceived physical work capacity, stress, sleep disturbance and occupational accidents among firefighters working during a strike. Work Stress, 16(3), 264-274.

Mazur, M., Niciejewska M. 2016. Zagrożenia psychospołeczne - występowanie $i$ profilaktyka. In: Klimecka-Tatar, D., Pacana, A. (ed.). Systemy bezpieczeństwa w podmiotach gospodarczych. OWSMJiP, Częstochowa.

Niciejewska, M., Olejniczak, K. 2016. Techniki relaksacyjne jako środki redukcji stresu zawodowego. In: Żywiołek, J., Babicz, W. (ed.). Światowy Dzień Bezpieczeństwa $i$ Ochrony Zdrowia w Pracy. Wyd. Wydziału Zarządzania Politechniki Częstochowskiej.

Niciejewska, M., Klimecka-Tatar, D. 2018. Health problems among employees in small enterprises as a result of improper OHS management. MATEC Web of Conferences 183. 01012. https://doi.org/10.1051/matecconf/201818301012

Strahler, J., Ziegert, T. 2015. Psychobiological stress response to a simulated school shooting in police officers. Psychoneuroendocrinology, 51, 80-91. 
Ulewicz, R., Niciejewska, M. 2016. Zarządzanie stresem zawodowym - wybrane aspekty. In: Żywiołek, J., Babicz, W. (ed.). Światowy Dzień Bezpieczeństwa $i$ Ochrony Zdrowia w Pracy. Wyd. Wydziału Zarządzania Politechniki Częstochowskiej.

Van Mol, M., Nijkamp, M.D., Bakker, J., Schaufeli,W. B., Kompanje, E. J. O. 2018. Counterbalancing work-related stress? Work engagement among intensive care professionals. Australian Critical Care, 31, 234-241.

Warchol, M. 2010. Ocena ryzyka zawodowego - czynniki psychospołeczne. Wyd. PIP, Warszawa.

Wróblewska, M. (2006). Ergonomia, www.eduskrypt.pl. 